\title{
Survey for Sugarcane Diseases in Major Sugarcane Growing Areas of Andhra Pradesh, India
}

\author{
P. Kishore Varma ${ }^{1 *}$, Ch. Srilatha Vani ${ }^{1}$, P. B. Pradeep Kumar ${ }^{2}$, \\ V. C. Chandrasekhar ${ }^{1}$ and M. Bharathalakshmi ${ }^{1}$
}

${ }^{1}$ Regional Agricultural Research Station, Anakapalli 531001, Visakhapatnam, A.P., India

${ }^{2}$ DAATTC, Kondempudi, Visakhapatnam, A.P., India

*Corresponding author

\section{Ke y w o r d s \\ Survey, Sugarcane, Red rot, Wilt, mosaic, Pokkah boeng, Yellow leaf disease}

\section{Article Info}

Accepted: xx July 2020 Available Online: xx August 2020

\begin{abstract}
A B S T R A C T
Sugarcane is an important cash crop in India used as a main source of raw material for sugar and bioethanol production. Diseases are major constraints in sugarcane production leading to economic yield losses. A roving survey was conducted in coastal region (Visakhapatnam, Vizianagaram, Srikakulam, East Godavari and Krishna districts) of Andhra Pradesh from 2017-18 to 2019-20 crop seasons to identify the major diseases responsible for yield losses in sugarcane. Diseases caused by fungi and viruses were found to be the major threats to sugarcane cultivation in Andhra Pradesh. Fungal diseases like smut, wilt and Pokkah boeng were more prevalent in the areas surveyed and red rot incidence was seen in pockets where susceptible cultivars like Co 62175 and CoV 89101 are under cultivation. Wilt was recorded in genotypes, like Co 62175, CoA 92081, CoA 05323, CoA 14321, CoV 95101, 81V 46 and 2012V 23, in sugarcane monocropped areas. Sugarcane mosaic was found to be widespread in the varieties, CoV 09356 and CoA 92081, from formative stage to grand growth stage of the crop in most of the districts surveyed, but was of greatest concern in Visakhapatnam and East Godavari districts. Other viral disease, yellow leaf disease caused by Sugarcane yellow leaf virus, was prevalent in cultivars like CoV 09356 and CoA 11321 in East Godavari, Krishna and Visakhapatnam districts. Increased incidence of phytoplasmal disease, grassy shoot, was noticed in Vizianagaram and Srikakulam districts in the cultivars, CoA 14321 and Co 86032. Stray incidence of diseases like leaf fleck and stem rot caused by Sugarcane bacilliform virus and Schizophyllum species, respectively, were also noticed during the survey. Results of the study indicated emergence and spread of viral diseases like mosaic, yellow leaf disease and leaf fleck besides reduction in red rot incidence in the areas surveyed.
\end{abstract}

\section{Introduction}

Sugarcane is one of the major cash crops grown in Andhra Pradesh in an area of 1.02 lakh ha with a production of 80.6 lakh tonnes (DES, GOI, 2020). Over the past decade sugarcane production is in a decreasing trend in Andhra Pradesh that could be attributed to decrease in organic content of the soil, monocropping, increase in ratoon area, no seed replacement, several biotic and abiotic stresses, poor crop management, etc. Among 
these factors, biotic stress is one of the major constraints in sugarcane production leading to huge losses in cane yield and quality affecting sugarcane growers as well as sugar industry.

Several fungi, bacteria, viruses, phytoplasma and nematodes were known to infect sugarcane in India inciting about 55 diseases. An estimated loss in cane yield due to biotic stresses in India is about 10-15 per cent annually leading to reduced supply of raw material for sugarcane based industries (Viswanathan and Rao, 2011). Red rot was regarded as cancer of sugarcane inciting enormous damage to sugarcane crop. Yield and sugar recovery are drastically reduced in susceptible varieties due to red rot (Satyavir, 2003; Sharma and Tamta, 2015). With introduction of red rot resistant varieties, sugar industry was sustained and now it has been a practice to grow only resistant cultivars. However, the emergence of new pathotypes in Colletotrichum falcatum, the red rot pathogen, is responsible for occasional outbreaks of red rot in the new genotypes of sugarcane.

Smut and wilt are the other major fungal diseases observed in most of the sugarcane growing regions of the country. Incidence of smut reduces the height and girth of the cane, tillering ability of the plant, cane tonnage, total solids and sucrose content in cane juice and ratio of sugars to fiber making sugar extraction difficult (Ramesh Sundar et al., 2012; Sandhu et al., 1969; Xiupeng et al., 2019). Similarly wilt infection reduces sett germinability, number of tillers, number of millable cane, cane yield, juice quality and commercial cane sugar in susceptible cultivars (Kumar et al., 2015).

Other fungal diseases like Pokkah boeng and stalk rot are also reported in India as emerging diseases in susceptible cultivars (Viswanathan et al., 2003; Vishwakarma et al., 2013). Viral diseases like yellow leaf disease, sugarcane mosaic, sugarcane streak mosaic, leaf fleck have become a major threat to a vegetatively propagated crop like sugarcane owing to degeneration of popular sugarcane cultivars (Viswanathan et al., 2007). Occasional incidence of bacterial diseases like leaf scald and red stripe were also reported from various parts of India. Phytoplasmal disease like grassy shoot was found endemic to certain parts of the country and identified as the most important disease of sugarcane in India (Chona, 1958). In view of the losses incited by various diseases and egress of new diseases in sugarcane, the present study was undertaken to assess the disease situation in major sugarcane regions of Andhra Pradesh in order to prioritize research work and suggest suitable management practices to the sugarcane farmers.

\section{Materials and Methods}

A roving survey was conducted during the period from 2017-18 to 2019-20 in the operational areas of sugar factories, viz., The Chodavaram Co-operative Sugars, Govada, Visakhapatnam; EID Parry India limited, Sankili, Srikakulam; The Etikoppaka Cooperative Agricultural Industries, Etikoppaka, Visakhapatnam; The Thandava Co-operative Sugars Limited, Payakaraopeta, Visakhapatnam; Nava Bharat Ventures, Samalkot, East Godavari; Sri Vijayarama Gajapathi Co-operative Sugars Ltd., Bhimsinghi, Vizianagaram, NCS Sugars Ltd., Latchayyapeta, Bobbili, Vizianagaram; and $\mathrm{KCP}$ sugar and Industries Corporation Limited, Vuyyuru, Krishna district.

As the risk of infections is more in ratoon crops, as they are exposed to pathogen inoculum for greater period, the inspections were concentrated on ratoons and wherever no suitable ratoon crops are available, plant 
crops were selected. As the fields are regularly inspected by the field staff of sugar factories, the fields with established infections and susceptible varieties were visited on priority basis. The per cent disease incidence, i.e., the number of proportion of diseased plants in a population was recorded (Campbell and Neher, 1994).

\section{Results and Discussion}

During survey, various diseases of sugarcane incited by fungi, bacteria and viruses were noticed in different areas. Diseases caused by fungi and viruses were found prevalent compared to bacterial diseases. The distribution of various diseases in the areas surveyed and their prevalence in different sugarcane cultivars is presented in Fig. 1.

\section{Fungal diseases}

Red rot, smut, Pokkah boeng and wilt are the common diseases observed during the survey conducted in North Coastal, East Godavari and Krishna districts of Andhra Pradesh. The incidence and distribution of various fungal diseases in different districts surveyed and the disease susceptibility of various cultivars is discussed in detail.

\section{Red rot}

During the survey, red rot incidence was noticed in areas where the susceptible cultivars are still under cultivation. Over three years of survey, an incidence of 15 to 20 percent was noticed in Juttada village of Chodavaram mandal of Visakhapatnam in the sugarcane cultivar, Co 62175. Though the cultivation of this cultivar, a mid-late variety released in 1982, is discouraged, some farmers of Juttada village are habituated to grow this variety due to high cane yield. Same is the case with another susceptible cultivar, $\mathrm{CoV}$ 89101, which is cultivated by the farmers of Munagapaka mandal of Visakhapatnam district for Jaggery making. An incidence of about 10 to 15 per cent was recorded every year in Munagapaka mandal.

The disease manifests as yellowing of foliage followed by drying of tops and the longitudinal sectioning of the cane revealed red discoloration with crosswise white patches and acid sour odour. However, the area under these susceptible cultivars in Visakhapatnam district is under decreasing trend over the years of survey with the popularization of red rot resistant cultivars like CoA 92081 (87A 298) and CoA 14321 (2009A 107), 2006A 102 (CoA 12322) and CoA 11321 (2005A 128) released from RARS, Anakapalli. The results obtained during the survey are in accordance with that of Kumar and Kumar (2018) who reported decline in red rot after 2012-13 crop season due to shift in cultivar selection.

\section{Smut}

Smut incidence was found to be high in all the areas surveyed in the sugarcane cultivar, CoA 92081. High smut incidence was observed in North coastal districts of Andhra Pradesh compared to other districts surveyed as 80 per cent of the area is under smut susceptible cultivar, CoA 92081. Smut incidence was high in ratoon crop compared to plant crop and the disease incidence was more during formative stage of the crop which usually coincides with the summer months. Moderate incidence of smut was noticed in other sugarcane cultivars like CoV 09356 (5-10\%), CoA 7602 (5-10\%), Co 86032 (10-15\%) and 93V $297(10-15 \%)$. The disease is easily identified by the emergence of long black whip like structure emerging from the tip of the shoot which is initially covered with a thin transparent membrane and the affected tillers turns lanky reducing the cane yield drastically. 


\section{Wilt}

Wilt incidence was observed in pockets in various districts surveyed, where monocropping is in vogue. An incidence of 5 to 30 per cent was recorded in Visakhapatnam, Srikakulam, East Godavari and Krishna districts of Andhra Pradesh. High disease incidence (10-30\%) was noticed in Divili and Kandrakota villages of Peddapuram mandal of East Godavari district in the sugarcane variety CoV 95101 (91V 83), where farmers practice water retention in alternate furrows during irrigation. Similarly, 20 to 30 percent of wilt was noticed in $2010 \mathrm{~V}$ 32 in Veerankilock village of Pammidimukkala mandal of Krishna district. Considerable amount of disease was found in the sugarcane genotypes, Co 62175, CoV 89101, CoA 92081, CoA 05323, CoA 14321 and $\mathrm{CoV} 89101$ in the areas surveyed.

The disease manifests as yellowing of foliage followed by drying and shrinking of stalks. Longitudinal sectioning of stalk expose reddening of internal tissues with boat shaped cavities extending between the nodes filled with mycelial growth of the pathogen in advanced stages of infection. Sometimes, combined infection of wilt and red rot were noticed in sugarcane cultivars Co 62175 and $\mathrm{CoV}$ 89101. Further, combined infection of stalk rot and wilt was also noticed in CoA 92081 in Subhadrayammapeta village of Tuni mandal of Viswanathan (2013) reviewed the progress of wilt in India and stated that the disease incidence ranged from traces to 75 per cent in different varieties in India affecting sugarcane production and productivity. He also emphasized the combined infection of red rot and wilt in Northern states and aggravation of the disease due to root borer. Similar observations were made during the present survey in varieties like Co 62175 and CoV 89101 in Visakhapatnam district.

\section{Pokkah boeng}

Pokkah boeng disease of sugarcane incited by Fusarium sacchari was noticed in all the districts surveyed in sugarcane genotypes like CoA 14321, CoA 05323, 87A 380, CoLk 94023, Co 06030, 2012V 123, 93V 297 and Co 14002. Disease incidence was high (15$30 \%$ ) in the cultivars CoA 14321, CoA 05323 and 2012V 123 at formative stage in Jami and Seethanagaram villages of Vizianagaram district and Kallamvaripalem village of Krishna district, respectively. The symptoms observed include chlorotic patches at the base of the leaves to red stripes along the chlorotic area resulting in rotting of the top portion of the plant leading to formation of internodal cavities and wilting of affected tillers. In young plants twisting of foliage coupled with chlorosis was noticed.

\section{Viral and phytoplasmal diseases}

Disease symptoms incited by several viruses and their combinations, viz., Sugarcane mosaic virus, Sugarcane streak mosaic virus, Sugarcane bacilliform virus, Sugarcane yellow leaf virus, were noticed during the survey and etiology was confirmed through ELISA and RT-PCR assays in case of mixed infections. Sugarcane mosaic and yellow leaf disease were found predominant in susceptible cultivars like CoV 09356 and Co 86032 in most of the areas surveyed.

\section{Mosaic}

Sugarcane mosaic was recorded during the survey from formative stage of the crop in the varieties, CoA 92081, CoV 09356, CoA 7602, Co 7805 and $91 \mathrm{~V} \mathrm{83,} \mathrm{in} \mathrm{most} \mathrm{of} \mathrm{the} \mathrm{areas}$ surveyed especially in ratoon crops. Mosaic incidence was high (15-35\%) in the sugarcane variety, 2003V 46, in PS Peta village of Chodavaram mandal, Visakhapatnam district. Severe incidence of mosaic in early stages of 
crop growth was found detrimental to the crop as it completely retards the plant growth and death of the plants is not uncommon. As most of the sugarcane area is under rainfed conditions in North coastal districts of Andhra Pradesh, delayed application of fertilizers till the occurrence of monsoon rains is a common practice, thus reducing the plant vigour, thereby making the plants easily prone to viral diseases.

Once the virus enters into the plant system it multiplies and spreads to all parts of the plants and the first symptoms are evident in the foliage as mottling of the leaves followed by yellowing and reddening of the leaves along the leaf margins starting from the tip.

Stunting of the affected plants was noted in most of the areas surveyed in susceptible cultivars. Aphids like sugarcane aphid and rusty plum aphid were commonly observed in various districts surveyed aiding in the horizontal spread of the disease under favourable conditions. According to Perera et al., (2012), varietal susceptibility, strain of the virus, vector population and prevailing weather conditions have a marked influence on mosaic incidence and severity (Table 1 and 2).

Table.1 Incidence of sugarcane diseases in North Coastal districts of Andhra Pradesh

\begin{tabular}{|c|c|c|c|c|c|c|c|c|}
\hline \multirow{2}{*}{$\begin{array}{l}\text { District/ mandals } \\
\text { surveyed }\end{array}$} & \multicolumn{8}{|c|}{ Per cent disease incidence $(\%)$} \\
\hline & Variety & Red rot & Smut & Wilt & $\begin{array}{c}\text { Pokkah } \\
\text { boeng }\end{array}$ & Mosaic & YLD & $\begin{array}{c}\text { Grassy } \\
\text { shoot }\end{array}$ \\
\hline \multirow{9}{*}{$\begin{array}{l}\text { Visakhapatnam } \\
\text { (Chodavaram, } \\
\text { Munagapaka, } \\
\text { Kasimkota }\end{array}$} & Co 62175 & $15-20$ & $5-10$ & $10-15$ & - & - & $5-15$ & - \\
\hline & CoV 89101 & $10-20$ & - & $1-5$ & - & - & - & - \\
\hline & CoA 92081 & - & $5-25$ & $10-15$ & - & $5-10$ & $5-15$ & - \\
\hline & CoV 09356 & - & $5-10$ & - & - & $15-35$ & $5-30$ & - \\
\hline & CoA 7602 & - & $5-10$ & - & - & $5-10$ & $5-10$ & \\
\hline & Co 7805 & - & - & - & - & $5-10$ & - & $10-15$ \\
\hline & CoA 12322 & - & - & - & - & - & $20-30$ & - \\
\hline & CoA 05323 & - & - & $20-30$ & - & - & - & - \\
\hline & CoA 14321 & - & - & $10-15$ & $5-10$ & - & - & $10-15$ \\
\hline \multirow{4}{*}{$\begin{array}{l}\text { Vizianagaram } \\
\text { (Jami, } \\
\text { Cheepurupalli, } \\
\text { Bobbili, } \\
\text { Seethanagaram, } \\
\text { Salur) }\end{array}$} & CoA 92081 & - & $10-20$ & - & - & $5-10$ & - & - \\
\hline & CoV 09356 & - & $5-10$ & - & - & - & - & $5-10$ \\
\hline & CoA 14321 & - & - & - & $10-15$ & - & - & $15-20$ \\
\hline & CoA 05323 & - & - & - & $20-30$ & - & - & - \\
\hline \multirow{6}{*}{$\begin{array}{l}\text { Srikakulam } \\
\text { (Palakonda, Regidi } \\
\text { Amadalavalasa) }\end{array}$} & Co 86032 & - & $10-15$ & - & - & - & $20-25$ & $15-20$ \\
\hline & $93 \mathrm{~V} 297$ & - & $10-15$ & - & - & - & $15-20$ & - \\
\hline & $81 \mathrm{~V} 46$ & - & - & $10-15$ & - & - & - & - \\
\hline & CoA 14321 & - & - & - & - & - & - & $15-20$ \\
\hline & CoA 92081 & - & - & - & - & - & - & $1-5$ \\
\hline & CoV 09356 & - & - & - & - & $10-15$ & - & - \\
\hline
\end{tabular}


Table.2 Incidence of sugarcane diseases in East Godavari and Krishna districts of Andhra Pradesh

\begin{tabular}{|c|c|c|c|c|c|c|c|c|}
\hline \multirow{2}{*}{$\begin{array}{l}\text { District/mandals } \\
\text { surveyed }\end{array}$} & \multicolumn{8}{|c|}{ Per cent disease incidence $(\%)$} \\
\hline & Variety/ Genotype & Red rot & Smut & Wilt & Pokkah boeng & Mosaic & YLD & $\begin{array}{l}\text { Grassy } \\
\text { shoot }\end{array}$ \\
\hline \multirow{9}{*}{$\begin{array}{l}\text { East Godavari } \\
\text { (Kirlampudi, Tuni, } \\
\text { Samalkot, } \\
\text { Rajahmundry Rural, } \\
\text { Pithapuram, } \\
\text { Peddapuram, } \\
\text { Jaggampeta, } \\
\text { Yeleswaram) }\end{array}$} & CoV 09356 & - & - & - & - & $10-15$ & $5-30$ & - \\
\hline & CoA 92081 & - & $5-20$ & $10-20$ & - & $5-30$ & $1-5$ & - \\
\hline & CoV 95101 & - & - & $10-30$ & - & $5-10$ & - & - \\
\hline & CoV 92102 & - & - & - & - & - & $5-10$ & - \\
\hline & Co 86032 & - & - & - & - & - & $20-30$ & - \\
\hline & $87 \mathrm{~A} 380$ & - & - & - & 5 & - & - & - \\
\hline & CoLk 94023 & - & - & - & $5-10$ & - & - & - \\
\hline & Co 06030 & - & - & - & $1-5$ & - & - & - \\
\hline & VSI 03102 & - & - & - & - & - & $10-30$ & - \\
\hline \multirow{9}{*}{$\begin{array}{l}\text { Krishna (Chellapalli, } \\
\text { Kankipadu, Movva, } \\
\text { Pammidimukkala, } \\
\text { Totlavalluru, } \\
\text { Vuyyuru) }\end{array}$} & CoA 92081 & - & $5-10$ & - & - & - & - & - \\
\hline & 2012 V 123 & - & - & - & $5-30$ & - & - & - \\
\hline & CoV 09356 & - & - & - & - & - & $5-20$ & - \\
\hline & 93V 297 & - & - & - & 5 & - & $5-15$ & $2-3$ \\
\hline & CoA 11321 & - & - & - & - & - & $15-20$ & - \\
\hline & Co 18009 & - & - & - & - & - & - & $5-10$ \\
\hline & 2010V 32 & - & - & $20-30$ & - & - & - & - \\
\hline & Co 14002 & - & - & - & $5-10$ & - & - & - \\
\hline & 2011V 127 & - & - & - & - & - & $2-5$ & - \\
\hline
\end{tabular}

Fig.1 Diseases observed during the survey. A) Smut in CoA 92081, B) Red rot in CoV 89101, C) Pokkah boeng in CoA 05323, D) Wilt in 2012V 32, E) Schizophyllum stem rot in CoV 09356, F)

Red rot in Co 62175, G) YLD in CoV 09356, H) Mosaic in CoV 09356 and I) Grassy shoot disease in CoA 14321

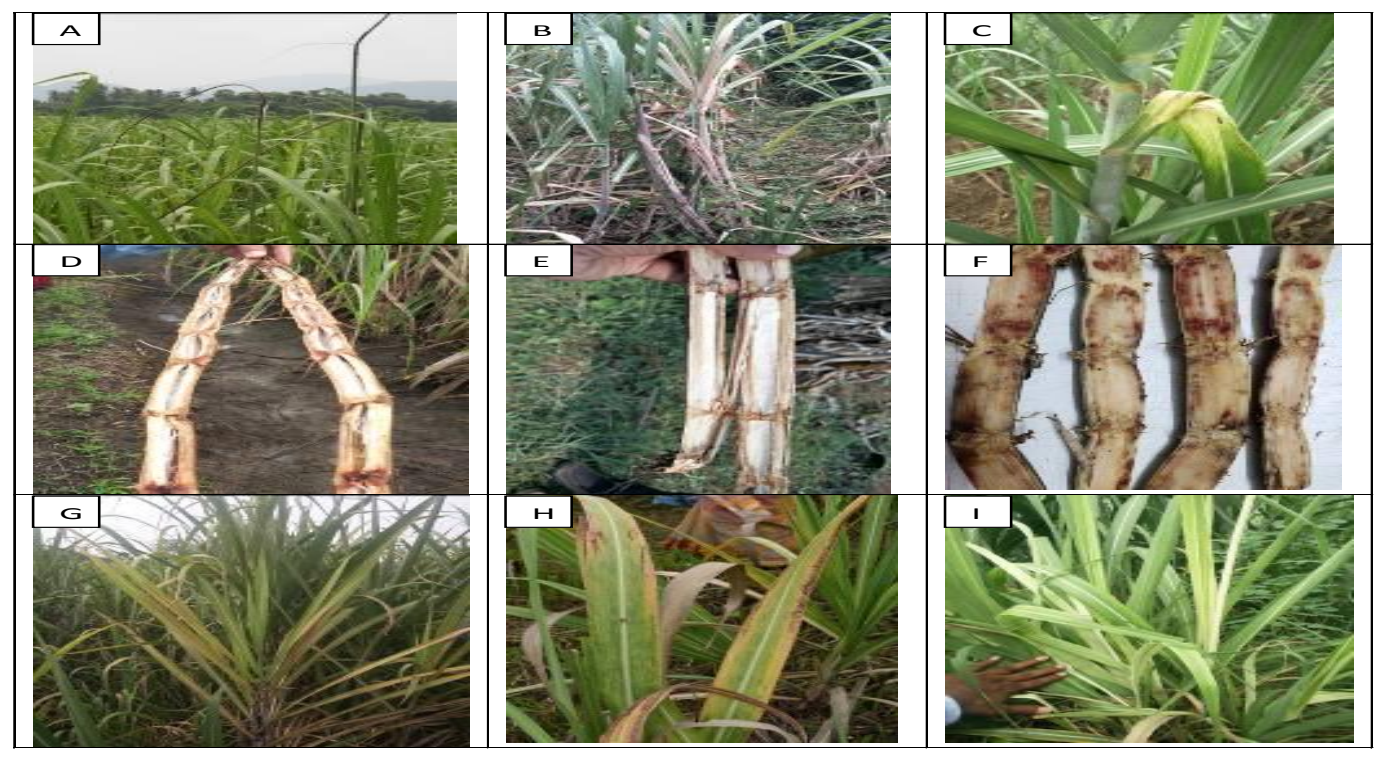




\section{Yellow leaf disease}

Sugarcane yellow leaf disease (YLD), caused by an RNA virus, Sugarcane yellow leaf virus, is an emerging disease inciting huge losses to sugarcane growers. Among the districts surveyed, highest incidence was noticed in East Godavari followed by Visakhapatnam, Krishna and Srikakulam. The sugarcane cultivars, Co 86032, CoV 09356, CoA 12322 and CoA 11321 were found highly susceptible to YLD. The symptoms manifested as midrib yellowing gradually progressing to leaf margins followed by drying of foliage from tip backwards and the disease could be easily identified from a distance by erect fan like appearance of foliage in advanced stages of infection. In Lakavaram village of Chodavaram mandal of Visakhapatnam district, stem rot was found associated with YLD affected canes in sugarcane cultivar, CoA 12322 leading to drying of entire plants in grand growth stage. Similarly, Schizophyllum rot of sugarcane was observed (10\%) in the variety, CoV 09356 in one of the fields surveyed in Peravaram village of Atreyapuram mandal, East Godavari district primarily infected by Yellow leaf disease.

\section{Grassy shoot}

A phytoplasmal disease was noticed during surveys in Vizianagaram, Srikakulam, Visakhapatnam and Krishna districts. Highest disease incidence was recorded in Vizianagram and Srikakulam districts in the sugarcane cultivars, CoA 14321 and Co 86032. Grassy shoot disease (GSD) was also noticed in other sugarcane varieties like Co 7805, 93V 297 and Co 18009. Stunted, bushy appearance of the plant with thin, small, slender tillers emanating from the base of the stool with pale yellow or white reduced leaves are the characteristic symptoms of the disease observed (Rane and Dakshindas, 1962). This disease cause significant losses to sugarcane yield and recovery and spreads rapidly to newer locations with infected setts and leafhopper vectors.

Though tetracyclines were known to inhibit the phytoplasmal growth upon sett treatment, only temporary remission of symptoms was reported (Kaewmanee and Hanboonsong, 2011). Previous studies also established the efficacy of hot air treatment $\left(54^{\circ} \mathrm{C}\right.$ for 4 hours) for grassy shoot disease management (Friso and Putter, 1993). However, the limited access to the hot air treatment device to the farmers and the difficulty in handling huge seed material is a great set back in imposing the treatment. Hence, it is important to detect the phytoplasmal infection through molecular methods at an early stage and to adopt clean seed programme, use of resistant cultivars and following appropriate cultural practices could restrict further spread of GSD (Rao et al., 2012).

In addition to major fungal and viral diseases, orange rust and ring spot were also noticed in cultivars like CoA 92081 and CoA 14321 in most of the areas surveyed. However, these diseases are considered of minor importance as the incidence of these diseases is seen at the maturity stage of the crop.

In conclusion, overall, the study revealed that the disease distribution was found predominantly influenced by the prevailing weather conditions, genotypes cultivated and the number of ratoons practiced. Disease severity is high in ratoon crops compared to plant crop irrespective of the areas surveyed. Smut disease was prevalent in all the districts surveyed in the sugarcane variety CoA 92081, especially in ratoon crops. Similarly, viral diseases like mosaic and YLD were severe in sugarcane variety $\mathrm{CoV} 09356$ which occupies more area in East Godavari and Krishna districts of Andhra Pradesh. Red rot and 
yellow leaf disease incidence were in a decreasing trend with popularization of red rot resistant cultivars and use of cane from tissue culture plant crop, respectively. Sugarcane mosaic incidence is in an increasing trend in almost all the areas surveyed irrespective of the varieties cultivated leading to degeneration of popular varieties in Andhra Pradesh. Increased grassy shoot incidence was observed in Vizianagaram and Srikakulam districts in cultivars like CoA 14321 and Co 86032. The diseases could be reduced by the adoption of clean seed programme in a phased manner based on prevalence of diseases, avoiding monocropping of sugarcane, timely adoption of plant protection measures, reducing the number of ratoons and adoption of clean cultivation practices.

\section{Acknowledgements}

The authors would like to thank all the Managing Directors, Chief Agricultural Officers and field staff of all the Sugar factories in East Godavari, Krishna, Visakhapatnam, Vizianagaram and Visakhapatnam districts for extending their co-operation during the present survey.

\section{References}

Campbell, C.L. and Neher, D.A. 1994. Estimating disease severity and incidence. In: Epidemiology and management of root diseases, Springer, Berlin, Heidelberg, 117-147.

Chona, B.L. 1958. Some disease of sugarcane reported from India in recent years. Indian Phytopathology 11:1-9.

Directorate of Economics and Statistics (DES), Ministry of Agriculture, Government of India website accessed on 29.06.2020. https://aps.dac.gov.in/APY/Public_Repo rt1.aspx
Friso, E.A. and Putter, C.A.J. 1993. FAO/IBPGR technical guidelines for the safe movement of sugarcane germplasm. Food and Agriculture Organization of the United Nations/ International board for Plant Genetic Resources, Rome, Italy.

Kaewmanee, C. and Hanboonsong, Y. 2011. Evaluation of the efficiency of various treatments used for sugarcane white leaf phytoplasma control. Bulletin of Insectology 64: 197-198.

Kumar, S., Chand, G., Mandal, D., Kumar, A. and Kumar, S. 2015. Deterioration in sugarcane due to wilt disease. Ecology, Environment and Conservation 21: 145148.

Kumar, N.R. and Kumar, K.V.K. Distribution scenario of major diseases of sugarcane in Andhra Pradesh, India. International Journal of Pure and Applied Bioscience 6(3): 425-431.

Perera, M.F., Fillipone, M.P., Noguera, A.S., Cuenya, M.I. and Castagnaro, A.P. 2012. An overview of the sugarcane mosaic disease in South America. Functional Plant Science and Biotechnology 6(2): 98-107.

Ramesh Sundar, A., Barnabas, E.L., Malathi, P. and Viswanathan, R. 2012. A Minireview on smut disease of sugarcane caused by Sporisorium scitamineum, Botany, Dr. John Mworia (Ed.), ISBN: 978-953-51-0355-4, InTech, Available from:

http://www.intechopen.com/books/bota ny/-a-mini-review-on-the-status-ofsmut-disease-of-sugarcane-caused-bysporisorium-scitamineum

Rane, M.S. and Dakshindas, D.G. 1962. The sugarcane disease "albino" or "grassy shoot”? Indian Sugar 12: 179-180.

Rao, G.P., Mall, S. and Marcone, C. 2012. Recent biotechnological approaches in diagnosis and management of sugarcane phytoplasma iseases. Functional Plant 
Science and Biotechnology 6(2): 19-29. Sandhu, S.A., Bhatti, D.S. and Rattan, B.K. 1969. Extent of losses caused by smut (Ustilago scitaminea Syd.) Journal of Research (PAU) 6: 341-344.

Satyavir, S. 2003. Red rot of sugarcaneCurrent Scenario. Indian Phytopathology 56: 245-254.

Sharma, R. and Tamta, S. 2015. A review on red rot: The cancer of sugarcane. Journal of Plant Pathology and Microbiology S1: 003. doi: 10.4172/2157-7471

Vishwakarma, S.K., Kumar, P., Nigam, A., Singh, A. and Kumar, A. 2013. Pokkah boeng: An emerging disease of sugarcane. Journal of Plant Pathology and Microbiology 4: 170 doi: 10.4172/2157-7471.1000170.

Viswanathan, R. 2013. Status of sugarcane wilt: One hundred years after its occurrence in India. Journal of Sugarcane Research 3(2): 86-106.
Viswanathan, R. and Rao, G.P. 2011. Disease scenario and management of sugarcane diseases in India. Sugar Tech 13(4): DOI: 10.1007/s12355-011-0102-4

Viswanathan, R., Balamuralikrishnan, M. and Ramar, K. 2007. Sugarcane mosaic in India: A cause of combined infection of sugarcane mosaic virus and sugarcane streak mosaic virus. Sugar Cane International 25: 6-14

Viswanathan, R., Premachandran, M.N., Balamuralikrishnan, M. and Jothi, R. 2003. A new stalkrot disease of sugarcane caused by Phaeocytostroma sacchari in India. Sugar Tech 5: 61-64.

Xiupeng, S., Fenglian, M., Krishan, K.V., Jinju, W., Xiaoqiu, Z., Litao, Y., Yang, R.L. 2019. Effect of sugarcane smut (Ustilago scitaminea Syd.) on ultrastructure and biochemical indices of sugarcane. Biomedical Journal of Scientific and Technical Research 17(1): 12546-12550.

\section{How to cite this article:}

Kishore Varma, P., Ch. Srilatha Vani, P. B. Pradeep Kumar, V. C. Chandrasekhar and Bharathalakshmi, M. 2020. Survey for Sugarcane Diseases in Major Sugarcane Growing Areas of Andhra Pradesh, India. Int.J.Curr.Microbiol.App.Sci. 9(08): 1865-1873. doi: https://doi.org/10.20546/ijcmas.2020.908.213 